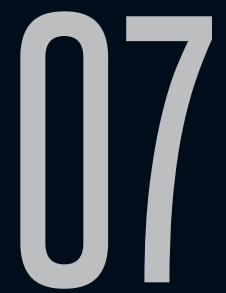

\title{
O VAMPIRO COMO METÁFORA NA LITERATURA BRASILEIRA OITOCENTISTA
}

Ana Paula Araujo dos Santos (UERJ)

Recebido em 13 mar 2019. Aprovado em 22 mai 2019.
Ana Paula Araujo dos Santos é Doutoranda em Teoria da Literatura e Literatura Comparada pela UERJ, com a pesquisa intitulada "A vertente feminina do Gótico nas literaturas britânica e brasileira". É bolsista CAPES, membro do grupo de pesquisa "Estudos do Gótico" (CNPq) e integrante do GT "Vertentes do Insólito Ficcional". É autora da dissertação $O$ Gótico feminino na Literatura Brasileira: um estudo de Ânsia eterna, de Júlia Lopes de Almeida (2017) e coorganizadora do livro As Artes do Mal: Textos Seminais (2018), publicado em conjunto com o Prof. Dr. Júlio França. Seus artigos mais recentes podem ser encontrados na página "Sobre o Medo" (sobreomedo.wordpress.com). Lattes: http://lattes.cnpq. br/0205036448892276. E-mail: ana_ads@hotmail.com.

Resumo: Nas literaturas de língua inglesa e na literatura francesa o interesse pelo mito do vampiro pode ser facilmente observado na ampla produção ficcional do século XIX e XX. Já no Brasil, até a metade do século $X X$ não houve uma produção sistemática de uma ficção que explorasse o mito do vampiro semelhante à da Inglaterra e da França. Contudo, a figura do vampiro se faz presente em obras brasileiras que exploram o seu potencial simbólico. Nelas, o vampiro aparece como figuração de morte, doenças e maldades. O presente artigo visa a uma análise dessas obras, mais especificamente dos contos "A esteireira" (1898), de 
Afonso Arinos, e "Noites brancas" (1920), de Gastão Cruls, além do romance A mortalha de Alzira (1891), de Aluísio Azevedo. As leituras propostas focarão em elementos característicos da temática do vampirismo na literatura: misteriosos encontros noturnos, femme fatales, desregramentos sexuais, perigos de doença e de contágio. Tais características funcionarão como ponto de partida para uma reflexão sobre as razões da suposta ausência, na literatura brasileira oitocentista, daquele que é um dos personagens mais recorrentes na literatura do mal e do medo e da literatura gótica.

Palavras-chave: Narrativa; Século XIX; Literatura Brasileira; Vampiros.

Abstract: In English and French literature, the interest in the myth of the vampire can be easily found in the vast fictional production published throughout the nineteenth and twentieth centuries. However, in Brazil, until the middle of the twentieth century there was no systematic production of fictional works that explored this myth in a similar way, although the vampire is present in Brazilian narratives that explore its symbolic potential. In these narratives, the vampire appears as a representation of death, diseases and evil. This paper aims at analyzing these works, specifically the short stories "A esteireira" (1898), by Afonso Arinos, and "Noites brancas" (1920) by Gastão Cruls, and also the novel A mortalha de Alzira (1891) by Aluísio Azevedo. The readings will focus on characteristic elements of vampirism in literature: mysterious nocturnal rendezvous, femme fatales, sexual transgressions, and the perils of diseases and contagion. These elements will guide a reflection about the possible reasons for the supposed absence in the nineteenth and early twentieth centuries Brazilian literature of one of the most recurrent characters in Gothic literature and the fiction that deals with evil and fear.

Keywords: Narrative; Nineteenth century; Brazilian literature; Vampires. 


\section{INTRODUÇÃO}

Por conta de sua constante presença na literatura, nas artes plásticas, no cinema, nos quadrinhos e em diversas outras produções artísticas, o vampiro assume uma existência quase mitológica em diversas culturas. Sua figura arquetípica não conhece barreiras geográficas nem temporais: pode ser encontrada nas narrativas orais e nas lendas de diversos países, e aparece metamorfoseado em muitas formas, nas mais diferentes épocas. Nick Groom (2018, p.XVIII-XIX) aponta que, no complexo folclore que cerca essa criatura, os vampiros se confundiram com uma série de outros seres sobrenaturais, tais como strix ou strigoi, lobisomens, revenants, espíritos noturnos $(A / p)$, bruxas e demônios. Além dessas criaturas, as mitologias egípcia, hebraica e mesmo a chinesa e a africana também possuem histórias de outros monstros malignos que têm em comum o fato de se alimentarem de sangue.

A pletora de ocorrências folclóricas relacionadas ao vampirismo ajuda a explicar não apenas a fascinante mitologia gerada em torno dessa figura, mas também as múltiplas faces que o vampiro assumiu - e continua assumindo - ao longo de sua existência cultural. Nas palavras de Nina Auerbach ${ }^{1}$ :

Mesmo antes de Drácula tornar-se foco das atenções com o início do século $X X$, os vampiros escaparam de resumir-se a uma única identidade. Eles eram portadores de paixões sensuais ou de doenças devastadoras; velhos de faces arroxeadas que devoravam seus filhos; donzelas suspirantes que às vezes se tornavam serpentes; impetuosos companheiros de jovens inquietos; ou mesmo plantas. $(2009$, p.4)

1 A exemplo desta, todas as demais citações em língua inglesa encontram-se em traduções minhas. 
A despeito de suas inúmeras caracterizações, as histórias sobre os vampiros convergem para um ponto em comum: seus personagens principais são mortos que voltam ao mundo dos vivos e atacam as suas vítimas à noite, em busca de sangue. Esse modus operandi particular foi visitado e revisitado por muitas narrativas literárias relacionadas ao mal, ao medo e ao Gótico. Afinal, interessada em provocar prazer estético por meio de emoções como o medo, o horror, o terror, a repulsa e a angústia, essa literatura de cunho negativo encontrou no vampiro um de seus mais ameaçadores e eficazes personagens vilanescos.

Esse interesse pode ser facilmente observado na ficção produzida ao longo do século XIX e XX. Em língua inglesa, o poema "Christabel" (1797-1816), de Samuel T. Coleridge, e o conto "O vampiro" (1819), de John Polidori, são apontados como textoschave para a inauguração de uma tradição vampírica na literatura. Porém, uma miríade de outras obras literárias em verso e em prosa se juntou a esses títulos, dentre os quais podemos citar como exemplos: "A Lâmia" (1819) e "La Belle Dame Sans Merci" (1819), de John Keats - poemas que apresentam sutis ligações com o tema do vampiro -, Carmilla (1872), de Sheridan Le Fanu, e Drácula (1897), de Bram Stoker. Na literatura francesa, o poema "As metamorfoses do vampiro", de Charles Baudelaire, e o conto "A morta amorosa" (1836), de Théophile Gautier, são exemplos significativos, em língua francesa, de uma ficção de temática vampiresca.

No Brasil oitocentista não houve uma produção sistemática de obras que explorassem o mito do vampiro semelhante à Inglaterra e à França. Contudo, a figura do vampiro se faz presente em obras brasileiras que o exploraram de forma simbólica. Nelas, o vampiro 
aparece como figuração de morte, doenças e maldades. São exemplos desse uso particular do arquétipo vampírico "A esteireira" (1898), de Afonso Arinos, o romance A mortalha de Alzira (1891), de Aluísio Azevedo, e "Noites brancas" (1920), de Gastão Cruls, que, publicado no início do século $X X$, é uma produção que possui evidentes características da nossa literatura oitocentista. Por meio da leitura dessas obras pretendo, ao longo deste ensaio, empreender uma breve reflexão acerca do uso metafórico do vampiro nessas narrativas e investigar as possíveis causas que contribuíram para impedir a difusão dessa criatura na literatura brasileira².

\section{DO MITO AO MONSTRO}

Antes de dar prosseguimento à análise do corpus ficcional, julgo necessário tecer algumas considerações sobre as características do vampiro na ficção. Sobre esse assunto, concordo com o teórico Jeffrey Jerome Cohen, para quem uma compreensão mais aprofundada das monstruosidades na literatura pressupõe também uma análise da cultura e das condições nas quais ela foi gerada. Cohen (2000, p.26) defende que é possível entender o monstro como uma "corporificação de um certo momento cultural - de uma época, de um sentimento e de um lugar". Essa afirmação se prova assaz correta no que diz respeito às criaturas vampíricas.

Em seu ensaio, o teórico frequentemente utiliza o vampiro como exemplo de personagem monstruosa - e não por acaso.

2 Uma versão prematura dessa exposição pode ser encontrada no artigo intitulado "Encontros noturnos em 'Noites Brancas', de Gastão Cruls: traços do vampirismo na literatura brasileira", publicado em "As arquiteturas do medo e insólito ficcional", nos Anais do XII Painel Reflexões sobre o insólito na narrativa ficcional (2014). Pretendo, com este trabalho, não apenas expandir as análises outrora empreendidas ao corpus ficcional referenciado, mas, também, desenvolver mais profundamente algumas das hipóteses conjecturadas nesse artigo. 
Ele demonstra que, em suas mais diversas aparições ficcionais na literatura e no cinema, o vampiro foi um monstro utilizado para representar diferentes ansiedades presentes em nossa sociedade. A ameaça representada por essa criatura tomava a forma de muitos dos nossos medos em relação à tirania e às enfermidades, e de nossas angústias ligadas à xenofobia, às práticas sexuais consideradas transgressivas, ao sadismo e à homossexualidade (COHEN, 2000, p.28-9). Tal como outras personagens monstruosas, ao encarnar uma variedade de transgressões socioculturais, ele demarca o que é tabu - e, a um só tempo, reafirma o que não é para a nossa cultura, para a nossa época.

Para Luciano Cabral (2017, p.220), a marca de alteridade seria, portanto, um dos traços definidores das monstruosidades ficcionais:

Quando enxergamos em outras pessoas características compatíveis com as nossas - sejam elas de ordem geográfica, linguística, cultural, étnica, sexual, econômica, política, social -, sentimo-nos seguros e, como não percebemos perigo, aproximamo-nos. Ao contrário, o que não se encaixa em nossos parâmetros de normalidade, por ser diferente, é combatido e rechaçado. Podemos dizer que é justamente nessa diferença onde residem os monstros. (CABRAL, 2017, p.221)

O vampiro - bem como os demais monstros em geral - seria um símbolo do que é diferente, e funcionaria como um indicador da alteridade. Esse é precisamente um entre os muitos motivos pelos quais os monstros nos suscitam receios. Porém, a sua alteridade não é apenas um atributo negativo. Se assim fosse, eles constituiriam uma ameaça mais óbvia, e, talvez, mais fácil de ser exterminada. No entanto, 
[p]or estarem associados a práticas proibitivas e transgressoras, monstros carregam em sua essência uma dupla característica: por violarem normas estabelecidas, são sempre perturbadores e ameaçadores e, pelo mesmo motivo, são sedutores e atraentes. Eles repelem na mesma proporção em que fascinam. (CABRAL, 2017, p.221)

Ao demarcar os limites do que é aceitável e do que é condenável e corporificar tabus sociais, o monstro realiza ficcionalmente muitas das nossas fantasias de violência e transgressão. Eles nos atraem por sua liberdade, porque, diferente das nossas, suas ações são irrestritas e não seguem os ditames sociais.

Além disso, entre os personagens monstruosos, os vampiros, em especial, adquiriram ao longo de sua existência literária uma aparência física sedutora. Muitos deles não possuem traços físicos repulsivos comuns a alguns monstros, mas, em vez disso, são dândis e femme fatales cuja beleza é responsável por atrair as suas vítimas a despeito do perigo que representam para elas. A emblemática passagem de Drácula em que Jonathan Harker se depara com as três vampiras prontas para "beijá-lo" é decerto um dos exemplos que melhor sumarizam o dúbio efeito do vampiro sobre suas presas:

As três damas tinham dentes alvos e brilhantes, que cintilavam nos lábios voluptuosos como pérolas sobre rubis. Havia algo naquelas mulheres que me perturbava: elas me provocavam uma inquietante mescla de atração e medo. Senti o perverso e sulfuroso desejo de que me beijassem com aqueles lábios vermelhos. 
Eu jazia imóvel, com os olhos semicerrados, espiando sob as pestanas, na angustiosa delícia da antecipação. Avançando, a moça loira se curvou sobre o meu corpo, e senti o toque de seu hálito - doce, sim, com ressaibos de mel que tilintaram em meus nervos como as notas de sua voz; mas no fundo daquela doçura havia um toque amargo e ofensivo, como um acre vestígio de sangue. (STOKER, 2014, p.107)

A reação de Harker diante do ataque é digna de nota: mesmo pressentindo o perigo, ele não resiste à sedução das vampiras. No excerto, fica claro que a beleza física e a luxúria das personagens monstruosas não excluem o terror da cena em que o prazer se mistura com o medo. Logo, se em alguns personagens monstruosos a aparência física repulsiva é uma marca de sua diferença em relação aos seres humanos e sinalizam o mal que podem causar a eles, em uma grande parte dos vampiros os atributos físicos são antes um disfarce, uma forma de atrair suas presas.

Essas reflexões ajudam a compreender as características que permitem considerar o vampiro como um monstro. Ora aterrorizantes ora fascinantes, o perigo representado pelos vampiros ficcionais vai além do mito. Demonstrarei a seguir que as características desse personagem arquetípico da literatura do mal não se restringem apenas ao ato de beber o sangue de suas vítimas, pois ele está ligado, também, a temas recorrentes da condição humana: a morte, a sexualidade e as enfermidades. É por meio desses topoi que a literatura brasileira do século XIX e do início do XX dialoga com a tradição das narrativas vampíricas. 


\section{PORQUE A ALMA DA CARNE ESTÁ NO SANGUE}

Afirmei anteriormente que o mito dos vampiros inclui uma grande variedade de criaturas sobrenaturais que possuem em comum a sede por sangue. Os simbolismos atribuídos a esse fluido vital não são poucos: sugar o sangue é, muitas vezes, descrito como um ato erótico, sádico, que mistura prazer e horror; noutras é descrito como um pecado, pois, conforme os versículos de Levítico (17:11), "a alma da carne está no sangue" (BÍBLIA, 1992, p.163). Assim, beber o sangue de outrem não é apenas letal, mas, também, algo vil e repulsivo.

As narrativas vampíricas costumam explorar os horrores advindos desse ato, ora de forma mais sutil ora de forma mais explícita. É por essa via que podemos considerar o conto "A esteireira", de Afonso Arinos, uma narrativa que dialoga com a tradição vampírica. Ainda que a criatura não seja mencionada diretamente nessa obra, a sede por sangue é o clímax da trama e é descrita de forma minuciosa como forma de horrorizar os leitores.

No conto, a protagonista de Arinos, Ana, é conhecida pela alcunha de esteireira por conta do pai, que fazia esteiras de taquara (ARINOS, 2006, p.52). Ela é apresentada para os leitores como uma mulher sensual e de personalidade forte. Sua descrição física, logo ao início da narrativa, é carregada de erotismo:

Era uma mulata de estatura regular, cheia de corpo, cadeiras largas e braços grossos. TremiamIhe as nádegas a seu passo forte. (...) OstentavaIhe invariavelmente o colo de nhambu, descoberto, aparecendo os seios duros, saltitantes, presos no bico pela renda da camisa alva. 
Tinha a pele macia e a carnadura cheia de viço que transudavam seus lábios vermelhos, sempre úmidos. As linhas do rosto, corretas que eram, representavam no conjunto de seu corpo o cunho da raça caucasiana. Esse conjunto aliava à graça da europeia a sensual indolência d'África.

Era provocadora - a mulata! (ARINOS, 2006, p.51-52)

Essa descrição faz com que associemos a esteireira a uma femme fatale. Esse arquétipo é conhecido por possuir uma beleza irresistivel, responsável por atrair os outros personagens e leválos à perdição e/ou à morte. Por conta disso, muitas das vampiras são consideradas femme fatales. A título de comparação, vale reproduzir aqui a cena em que Christabel, do poema homônimo de Coleridge, assiste Geraldine se despir:

Ela se ergueu, apoiada em seu cotovelo,

Para observar a donzela Geraldine.

Abaixo do lustre a dama se curvou,

E lentamente seus olhos se viravam;

E então fazendo cessar a respiração,

Como alguém que treme, ela desfez

A fita que trazia logo abaixo do colo:

Seu vestido de seda, e a anágua,

Caíram a seus pés, e inteira à mostra,

Oh! Seu peito e suas costelas -

Visão de sonho, não há palavras para ela! (COLERIDGE, 2010, p.249)

Embora mais sutil que a descrição dos atributos físicos da esteireira, a cena voyeurística é igualmente carregada de erotismo, e serve para destacar o encanto produzido por meio da beleza da vampira de Coleridge. Em ambos os casos, a identificação das personagens como femme fatales será importante para o 
desenvolvimento das narrativas, pois reafirmam o dúbio efeito causado pelas vampiras: elas são tão belas quanto são fatais.

Se é possível ser atraído pela beleza da esteireira, o desenvolvimento da trama evidencia que ela é uma mulher perigosa. Perdidamente apaixonada por Filipinho, um rapaz genioso, atrevido e envolvido com outros bandidos locais (ARINOS, 2006, p.53), Ana não admite que o seu amado flerte com outra mulher senão com ela. O narrador deixa claro que ela "era orgulhosa. Amava a Filipinho, julgando-o todo seu, dela só" (ARINOS, 2006, p.58). Essa paixão possessiva será o motivo que irá aproximar a personagem do vampirismo. Desconfiada de traição, Ana começa a revelar uma personalidade maligna que é simbolizada sobretudo pelos seus olhares:

Ao despedir-se do mulato, Ana, puxando-o pelos dedos e fixando nos dele seus grandes olhos negros, queimados de zelo, perguntou-lhe se não era exato ter ele dado umas bichas de ouro à Candinha do Fundão e estar inclinado a gostar dela. (ARINOS, 2006, p.55 - grifos meus)

Ana apareceu nesse dia, como sempre, asseada, com a saia de uma limpeza sem par. Trazia nos olhos um brilho estranho; seus olhares pareciam ferir como os espinhos dos gravatás, sobre os quais ela estendia algumas vezes a roupa.

É que o ciúme lhe trabalhara a alma todo o tempo decorrido desde a véspera.

(ARINOS, 2006, p.57 - grifos meus)

A vileza denunciada pelo olhar da esteireira é o primeiro indício do ato mau que ela está para cometer. No início do conto, nós, leitores, somos levados a acreditar que ela era apenas uma mulher de gênio forte, provocadora, mas o ciúme irá transfigurá- 
la em uma monstruosidade vampírica. Ana prepara uma armadilha para Candinha, sua suposta rival. Convida-a para um passeio que terminará no assassinato desta última:

Ana, sem que a companheira o percebesse, saca de uma navalha e, vibrando-a com a mão rápida e firme, corta a carótida à infeliz companheira, que estava unida a si, abraçada à sua cintura, na garupa do animal. Caíram ambas, e Ana, não querendo que na estrada houvesse grande marca de sangue, encostou os lábios ao lugar de onde irrompia aos cachões, e, carnívora esfaimada, chupou, chupou por muito tempo, carregando, depois, o corpo da desventurada para bem longe, onde um desses precipícios, cavados pelas enxurradas, recebeu-o no fundo da sua fauce. (ARINOS, 2006, p.60)

O narrador faz questão de apontar que o ciúme de Ana era infundado (ARINOS, 2006, p.58). Isso faz que com que o assassinato cometido por ela seja visto como um ato ainda mais maligno, afinal, há um descompasso entre a gravidade da transgressão cometida e a débil motivação do crime perpetrado pela esteireira (FRANÇA \& SANTOS, 2018, p.14).

Portanto, o que chama a atenção nessa transgressão é que a sua execução vai além de um mero crime. Ana ataca justamente a carótida de Candinha e suga o sangue com uma inexplicável sede. A justificativa para esse estranho comportamento provém do temor de que fossem deixados rastros do assassinato que a esteireira acabara de cometer - em nenhum momento temos alguma menção explícita a um ato de vampirismo. Contudo, é inevitável não relacionar a sede de Ana por sangue e o prazer com que ela parece beber o fluido vital da rival com um comportamento vampírico. Se o vampirismo 
não é mencionado diretamente no conto, ao menos é possível, em uma leitura atenta da obra, apontá-lo metaforicamente. Afinal, Ana, no clímax da narrativa, pouco diverge das vampiras do castelo de Drácula, de Lucy Westenra, de Carmilla ou de outras vampiras célebres. Seu aspecto vilanesco e monstruoso advém da mesma fonte que confere a monstruosidade a essas personagens: o fato de não apenas aniquilarem a sua vítima, mas fazê-lo ao ingerir a essência desta, isto é, o fluido vital do sangue.

\section{PORQUE O AMOR É MAIS FORTE DO QUE A MORTE}

O emprego metafórico do vampiro em "A esteireira" não é um caso isolado na literatura brasileira. Se, no conto de Afonso Arinos, o vampirismo simboliza um ato extremo de maldade cometido pela protagonista da trama, nas duas outras obras analisadas neste trabalho, esse personagem arquetípico irá incorporar outras facetas às quais o vampirismo está ligado - o sexo, as doenças e a transmissão delas do algoz para a sua vítima.

Em A mortalha de Alzira, Aluísio Azevedo homenageia o célebre conto vampiresco de Théophile Gautier, "A morta amorosa". Em ambas as narrativas, um jovem padre, puro e devotado a Deus apaixona-se por uma cortesã. O casal se reúne somente após o falecimento desta última, que volta ao mundo dos vivos todas as noites à procura do amado - provando, assim, que "o amor é mais forte do que a morte" (GAUTIER, 2010, p.148).

Embora compartilhem a mesma trama, as duas obras se desenvolvem de forma bastante distintas. No conto de Gautier, o padre Romualdo, o protagonista, é alertado que a cortesã Clarimunda é um ser demoníaco, uma vampira, e que teria morrido 
mais de uma vez (GAUTIER, 2010, p.146). Se de início Clarimunda aparece para ele como se fosse um sonho, a confirmação de que a femme fatale é real e um ser monstruoso ratifica que ela é uma ameaça para Romualdo, pois ela passa a se alimentar de seu sangue:

O sangue logo caiu em filetes purpúreos e algumas gotas jorraram em Clarimunda. Seus olhos se iluminaram, sua fisionomia tinha uma expressão de alegria feroz e selvagem como eu jamais vira. Saltou da cama com uma agilidade animal, uma agilidade de macaco ou de gato e se precipitou sobre o ferimento, que começou a sugar com indizível volúpia. Engolia o sangue em pequenos goles, lenta e preciosamente, como um gourmet um vinho de Xerez ou de Siracusa (...). De vez em quando, ela interrompia para beijar a minha mão, depois voltava a pressionar contra a ferida os seus lábios, para extrair ainda algumas gotas vermelhas de sangue. (GAUTIER, 2010, p.155)

- Eu não morrerei! Não morrerei! - disse ela meio louca de alegria, pendurando-se em meu pescoço. - Poderei te amar ainda por muito tempo. Minha vida está na tua, e tudo o que eu sou vem de ti. Algumas gotas de teu sangue rico e nobre, mais precioso e eficaz do que todos os elixires do mundo, me proporcionam a existência! (GAUTIER, 2010, p.156)

Com o passar do tempo, Clarimunda mantém-se viva apenas por meio do sangue do padre, porém, este último perde, aos poucos, a própria vida: é consumido pelo cansaço, pela angústia e pelos remorsos do romance com a morta-viva. O pesadelo de Romualdo só termina quando o seu guardião, o padre Serapião aniquila a vampira ao jogar água benta em sua tumba. O conto de Gautier realiza-se como uma clássica narrativa vampírica não apenas pelo 
ritual de extermínio da personagem, mas também porque na literatura - tanto quanto no cinema - a eliminação do vampiro é o clímax desse tipo de narrativa (LECOUTEUX, 2005, p.139).

Já no romance de Azevedo - tal como no conto de Arinos não há nenhuma menção direta ao vampirismo. Em um primeiro momento, a compreensão de A mortalha de Alzira como uma narrativa vampírica deve-se apenas ao inegável paralelismo com o conto de Gautier: todos os principais personagens e situações de "A morta amorosa" encontram seus correspondentes n'A mortalha excetuando-se a confirmação da femme fatale como uma vampira. Apesar disso, concordo com Marina Sena (2017, p.106), para quem a sugestão de vampirismo não foi completamente excluída do romance azevediano. A eliminação do elemento sobrenatural não impede que o vampiro seja explorado de outra forma ao longo da narrativa, como pretendo demonstrar a seguir.

No romance de Azevedo, o padre Ângelo, o protagonista, foi uma criança órfã adotada pelo padre Ozéas, que o tomou por um enviado divino, um messias para salvar a corrupta Paris do século XVIII. Ângelo foi criado dentro do convento, "fechado na sua religiosa estufa, sem ter nem ao menos desconfiança do que se passava lá fora (...)" (AZEVEDO, 1894, p.19). Até os vinte anos cresceu casto, conhecendo apenas a religião e a Bíblia (AZEVEDO, 1894, p.20). Sob a rígida educação de Ozéas, o jovem Ângelo foi afastado de todo e qualquer contato com o sexo de modo a permanecer fiel à vocação religiosa.

Essa informação é importante porque, segundo David Brown, Azevedo teria racionalizado os elementos de "A morta amorosa" não por acaso, mas com o intento de dar ao enredo uma configuração naturalista: 
No momento em que escrevia $A$ mortalha de Alzira, Aluísio Azevedo já era uma espécie de autoridade no que se referia à questão de dupla personalidade e à vida onírica das pessoas que, à noite, põem de lado suas inibições diurnas. De fato, toda a trama de uma de suas principais obras, 0 Homem (1887), foi arquitetada quase inteiramente em torno desse fenômeno psicológico, que é visto por Azevedo como uma manifestação de histeria. Não é surpreendente, portanto, que, ao escrever sua versão de A morta amorosa, Azevedo tenha escolhido essa explicação racional para o fenômeno documentado. (1945, p.253)

Mais interessado em explorar uma patologia do que um caso sobrenatural, Azevedo demonstra, em A mortalha de Alzira, como a privação sexual do padre Ângelo culmina em esquizofrenia e violência (BROWN, 1954, p.255). Esse tipo de narrativa não é incomum às obras naturalistas, que frequentemente postulavam a melancolia, a loucura e a morte como as sinas mais frequentes dos personagens aos quais era imposta a privação sexual (MENDES, 2016, p.345-346).

É nesse sentido que Ângelo, inexperiente e dotado de uma imaginação fantasiosa, irá gradativamente adoecer diante da impossibilidade de realizar os impulsos amorosos despertados pela cortesã Alzira. Na ocasião do primeiro encontro entre ambos, o jovem é fulminado por desejos que até então lhe eram desconhecidos, e, como resultado, é tomado por uma série de reações tipicamente atribuídas a personagens histéricos e/ou acometidos por alguma nevrose: convulsões, soluços, tremores e um contínuo choro (AZEVEDO, p.68-69). Tal reação não é sem motivo, afinal, até então Ângelo pouco conhecia do mundo, e, 
encerrado no claustro, permanecera ignorante às mulheres. A exposição a uma femme fatale como Alzira - uma "bela, cínica e espirituosa cortesã" (AZEVEDO, 1894, p.43) disputada por "toda a gente da corte capaz de manter mulheres caras" (AZEVEDO, 1894, p.43) - opera, no protagonista, uma mudança inevitável. Alzira se torna o objeto da obsessão romântica de Ângelo, o alvo de desejos inconciliáveis com a sua posição religiosa.

Tamanha obsessão leva o padre a sentir a presença de Alzira sempre que se encontra a sós (AZEVEDO, 1894, p.164-165). Logo, desde o início do affair entre ambos, Alzira assume um papel fantasmagórico: ela parece assombrar e ameaçar o padre, tal como um ser sobrenatural. Por conta disso, Ângelo se torna mais taciturno, mais fraco e mais infeliz diante da incapacidade de controlar a paixão e a luxúria despertadas pela cortesã (AZEVEDO, 1894, p.160). Essa situação tomará proporções ainda mais graves a partir do falecimento de Alzira. Alucinado, o padre principia a vê-la retornar da morte:

E uma vertigem se apoderou dele, e o seu sangue enlouqueceu, acendendo-Ihe os sentidos, e apagando-Ihe naquele instante a luz da razão.

Soltou um grito. Aos seus olhos desvairados, Alzira acabava de erguer-se a meio no leito, e abriu as pálpebras, estendendo-lhe os braços com um fugitivo e triste sorriso nos lábios.

- Meu Deus! meu Deus! exclamou ele, trêmulo e aterrorizado. Que significa isto?... Ainda vives, Alzira?... mas como é que vives, se o teu corpo tem a gelidez da morte?...

E Ângelo viu distintamente que os lábios dela se moviam, para lhe responder com uma voz quase indistinguível: 
- Sim, vivo ainda... um instante apenas, um ligeiro instante; o que baste para encher minha alma com a tua imagem imaculada e santa, antes que eu parta eternamente para as margens desconhecidas que já daqui avisto... (AZEVEDO, 1894, p.175-176)

A narrativa deixa evidente que os abalos nervosos e as alucinações de Ângelo não possuem origem sobrenatural, mas sim patológicas. Ele é, logo a seguir, diagnosticado como histérico, condição que teria desenvolvido por conta da imposição de pureza e castidade ao seu corpo e à sua alma. Nesse estado ele estaria sujeito a toda espécie de sonhos extravagantes, delírios, visões e fantasias (AZEVEDO, 1894, p.181-182). E é precisamente isso que acomete Ângelo ao longo da narrativa azevediana. Após a morte de Alzira, todas as noites, ao se deitar para dormir, ele passa a sonhar com a amada. Nesses sonhos, tal como uma rediviva, Alzira atravessa o mundo dos mortos e retorna ao mundo dos vivos. Fria como um cadáver, sua "nova existência" - exclusivamente noturna, pois se mantém presa ao sepulcro durante o dia - depende unicamente do calor do sangue de Ângelo e tem como objetivos fazer o padre gozar a vida profana que lhe fora negada e se entregar, finalmente, ao amor da cortesã (AZEVEDO, 1894, p.204-205).

Assim, embora Alzira não seja apontada como vampira, nos sonhos de Ângelo ela encarna perfeitamente esse arquétipo de personagem. O suposto retorno da cortesã ao mundo dos vivos torna-se o vetor para os delirantes desejos do histérico padre, que, todas as noites, sonha estar na companhia da amada, vivendo de forma extravagante durante a noite, repleto de luxúria, ambição e violência - uma vida incompatível com o cotidiano religioso diurno. O auge dessa dupla existência, e, também, da sugestão vampírica no 
romance azevediano, é a cena em que o padre, tomado de ciúmes, assassina um ladrão que ameaça roubar-lhe a amante:

- Hás de morrer! tornou o outro, abrasado de cólera. Nunca mais terás olhos para cobiçar a minha amante.

E, arrancando contra ele, atravessou-Ihe o peito com uma punhalada.

- Ai! gemeu o salteador agonizando.

- Fujamos! segredou Alzira, puxando o amante pelo braço.

- Não! Hei de beber-lhe primeiro o sangue! Hei de beber o sangue de todo aquele que pretende arrancar-te de meus braços!

E vergou-se sobre o cadáver, colando-Ihe os lábios à ferida que sangrava.

- Ângelo! Ângelo! Partamos! Olha que aí vem o dia! exclamou a cortesã.

O pároco ergueu então a cabeça e notou que, com efeito, em volta dele tudo começava a esbater-se à luz da aurora. O próprio cadáver, de cuja ferida ele acabava de despregar a boca cheia de sangue, nada mais era que uma transparente sombra, estendida a seus pés. (AZEVEDO, 1894, p.245)

Tal como em "A esteireira", a sede por sangue surge de um grave crime cometido pelo protagonista. Porém, não é a personagem vampírica que sucumbe à sede, mas o próprio protagonista. Embora em seu próprio sonho Ângelo tenha agido em legítima defesa, a sua motivação parece débil se comparada ao ato vampírico de beber o sangue da vítima e à ferocidade com que o padre o faz. Conforme chamei atenção anteriormente - ao analisar "A esteireira" -, 
também n'A mortalha a narrativa explora a descrição de beber sangue de uma vítima como forma de suscitar repulsa em seu leitor.

O romance de Azevedo se torna gradativamente mais sombrio à medida que a violenta e sensual vida noturna do padre passa a imperar sobre a sua vida religiosa. No epílogo da história, Ângelo descobre que sua vampírica companheira noturna e os sonhos extravagantes não eram senão uma ilusão, um produto de sua mente doente que desejava, sobretudo, dar vazão ao amor impossível de ser realizado quando Alzira estava viva. O jovem padre colapsa diante de tal verdade. Sem forças para encarar o que era real, ele se suicida, preferindo antes o sono eterno a uma vida sem sonhos (AZEVEDO, 1984, p.320).

Diante do exposto, é possível confirmar a hipótese que propus no início desta seção: Azevedo não deixa de explorar, em seu romance, o elemento central do vampirismo, isto é, o tabu do sangue e a repulsão causada por se alimentar desse líquido vital. Mesmo sem ratificar Alzira como uma vampira, a confirmação da monstruosidade sobrenatural é dispensável na narrativa, uma vez que a personagem assume características vampíricas, é descrita e age como uma rediviva. A personagem de Azevedo possui, sobretudo, a mesma função atribuída às outras vampiras ficcionais: é por meio de sua sedução que os personagens da narrativa caem em desgraça, enlouquecem e/ou morrem.

\section{PORQUE O BEIJO É A VÉSPERA DO ESCARRO}

A predominância de um ambiente noturno e a sede por sangue humano são as constantes da tradição literária ligada ao vampirismo - mesmo quando os personagens não são diretamente 
classificados como vampiros, mas podem ser entendidos dessa forma. Esse binômio é o cerne das narrativas vampíricas, e sobre ele é arquitetado "Noites Brancas", de Gastão Cruls. A trama é, de fato, tão semelhante às histórias vampíricas que a menção a essas criaturas não escapa à narração, em uma sugestão que não parece de modo algum gratuita.

No início do conto, o protagonista, Carlos de Azambuja, um estudante de quase dezoito anos, recebe um misterioso bilhete que lhe propõe o seguinte convite: "Carlos - Se tu queres conhecer a volúpia de meus beijos, deixa a tua porta aberta e, esta noite, quando todos dormirem, no mistério da treva e do silêncio, eu te virei proporcionar o mais lindo sonho de amor" (CRULS, 1951, p.59).

O bilhete, ao mesmo tempo em que "encalmava o sangue, acendendo-Ihe nas veias o fogo da luxúria" (1951, p.62), cria em Carlos uma hesitação que possui motivações morais: tendo ele se hospedado na fazenda do Coronel Jesus - onde as únicas presenças femininas eram a esposa do Coronel, D. Clarice, e as filhas Olga e Leonor -, obedecer à sua remetente significaria concordar com um intercurso sexual com uma das três mulheres. Em qualquer um dos casos, o romance seria visto como uma transgressão cometida contra o seu anfitrião. Apesar disso, Carlos, levado pelas tentações inferidas e imaginadas a partir do conteúdo do bilhete, cede ao convite e dá início aos encontros noturnos que se tornam o foco da trama de Gastão Cruls:

Não havia mais dúvidas: a sua porta teria que ficar aberta...

E ficou. Ficou e ela veio, não uma, mas muitas outras noites a seguir. 
Olga? Leonor? D. Clarice? Era o que Carlos não sabia e não cessava de se perguntar a si mesmo, desde a primeira vez em que, mal sopitando de emoção, tateara na treva e retivera entre os braços aquele cálido corpo de mulher, que todas as noites se intrometia no seu leito e lhe oferecia o seio à sofreguidão dos lábios febris. (CRULS, 1951, p.66)

A preferência da amante misteriosa pela noite aproxima-a do modus operandi de vampiros clássicos da literatura como a Carmilla, de Sheridan Le Fanu, e o Drácula, de Bram Stoker, cujos contínuos ataques às suas vítimas acontecem quando estas estão dormindo e possuem implicações inegavelmente sexuais, uma vez que "[o vampiro] não ataca simplesmente visando ao sangue, pois há a presença de um elemento erótico entre ele e sua vítima e os elementos eróticos ou libertinos ganham mais destaque na narrativa do que a necessidade de sangue" (SILVA, 2010, p.28). Um bom exemplo dessa asserção é a descrição de um dos muitos estranhos sonhos em que a jovem Laura, protagonista de Carmilla, é atacada, sem saber, pela célebre vampira dessa obra:

Algumas vezes eu sentia como se alguém passasse a mão ternamente, pelo meu rosto e pelo meu pescoço. Outras vezes, parecia que lábios mornos me beijavam com mais vagar e paixão à medida que se aproximavam de minha garganta, e ali as carícias se concentravam. Meu coração batia aceleradamente, minha respiração se tornava ofegante; surgia então um soluço, que parecia me estrangular e se transformava numa terrível convulsão, durante a qual eu perdia totalmente os sentidos. (LE FANU, 2010, p.96-97)

Ocorrências semelhantes a essa acontecem frequentemente após Laura se deitar para dormir, e são atribuídas à Carmilla, ao 
final da narrativa, quando sua verdadeira identidade vampírica é revelada aos demais personagens da obra. Seguindo essa mesma característica, a analogia entre a visitante noturna de "Noites brancas" e uma criatura vampírica é insinuada pelo narrador, e abre, para o leitor, a possibilidade de interpretar os encontros como eventos sobrenaturais:

Afigurava-se-Ihe mesmo uma negrejante vilania querer supor que aquela figura tão fina, tão angélica, tão espiritual, se pudesse transformar no vampiro luxurioso e insaciável, que todas as noites o possuía furiosamente, a arder na febre de mil desejos. Tão leves eram seus passos e tanta a treva que a cercava, que, não raro, Carlos só pressentia a amante quando ela, já abeirada do seu leito, deixava cair as vestes e uma onda de perfume se Ihe espalhava pelo quarto todo. (CRULS, 1951, p.68 - grifo meu)

Os movimentos leves, quase imperceptíveis da amante de Carlos, sua preferência pelas trevas e a sua rápida fuga ao raiar do dia conferem aos encontros amorosos uma atmosfera fantasmagórica. Somando isso à alusão à criatura sobrenatural, "Noites brancas" parece, de fato, relatar uma narrativa vampírica. Sem conhecer a identidade da visitante noturna, somos inclinados, como Carlos, a acreditar que ela é uma espécie de vampira.

Porém, ao final do conto de Cruls, o suspense acerca da identidade da personagem chega ao fim com um clímax que provoca uma reviravolta inesperada para o protagonista e para o leitor. Uma noite, a misteriosa amante de Carlos falta ao seu encontro, e, na manhã seguinte, o Coronel Jesus informa ao estudante que uma hóspede secreta da fazenda, Maria Clara, irmã de D. Clarice, veio a 
falecer por conta de um mal incurável que a consumia há tempos: a morfeia, doença conhecida hoje como lepra ou hanseníase. A misteriosa e vampírica amante de Carlos não era senão a irmã de D. Clarice, que vivia em segredo na fazenda, consumindo-se pouco a pouco pelo mal infeccioso e altamente transmissível. Após o relato do Coronel Jesus, a lembrança dos encontros noturnos torna-se imediatamente, para Carlos, uma fonte direta de repulsa:

Carlos, à medida que ouvia essa narrativa, sentia o coração aos pulos e sucessivos calafrios de terror Ihe percorriam os músculos. Um suor viscoso inundava-lhe o corpo, que todo se agitava num tremor nervoso.

(...)

Carlos sentia pela primeira vez na boca o travo daqueles beijos, que se muito o fizeram gozar, mais ainda o fariam sofrer. (CRULS, 1951, p.71)

O epílogo do conto recorda a advertência presente nos "Versos íntimos", de Augusto dos Anjos (s/d, p.105): "O beijo, amigo, é a véspera do escarro,/ A mão que afaga é a mesma que apedreja". Afinal, o luxurioso romance que Carlos compartilhara com a suposta vampira transforma-se, rapidamente, em uma projeção dos males que ele viria a sofrer, uma vez contaminado pela mesma doença responsável por causar o isolamento e a morte de Maria Clara.

Apontei, nas análises anteriores, que o vampiro é explorado como figuração de desejos proibidos, maldades e mortes. No conto de Cruls, no entanto, o caráter vampírico da amante de Carlos serve de metáfora para uma grave doença que é transmitida ao protagonista por meio do ato sexual. Esse não é um traço incomum às histórias de vampiro, pois, como informa Nick Groom (2018, 
p.15), "muitos relatos de vampiros associam surtos de vampirismo ao contágio, fazendo deles vetores, e, consequentemente, parte da história das doenças infecciosas." Historicamente, muitas mortes ocasionadas por surtos de doenças epidêmicas - que assolavam a Europa desde a época medieval - foram atribuídas a essas criaturas. Sem uma explicação científica adequada para o contágio e para a propagação desse tipo de doença, essas epidemias foram entendidas como pragas místicas, espalhadas por meio de forças invisíveis, capazes de circular e infectar por meios materiais e imateriais - por palavras, pela respiração e pelo sangue (GROOM, 2018, p.16). A partir daí, surgiu um forte vínculo entre o mito vampírico e as doenças infecciosas.

No caso de "Noites brancas", as peculiaridades da lepra permitem mesmo um paralelo com a própria condição vampírica, cuja maldição é frequentemente transmitida a outrem através do "beijo" do vampiro. Se, ao atribuir a causa dos males da história a uma enfermidade, Gastão Cruls atenua o elemento sobrenatural que permeia sua narrativa, optando por um desfecho realista, não se pode dizer o mesmo em relação à configuração vampírica da misteriosa personagem de "Noites brancas". Tal como Ana, a esteireira, e Alzira, Maria Clara enquadra-se no arquétipo de vampiro ao longo da obra, e, principalmente, em seu desfecho, quando transmite o seu mal a Carlos. Dessa forma, Gastão Cruls explora e mantém até o final da obra elementos que permitem ao leitor qualificá-la como uma história tipicamente vampiresca. 


\section{CONSIDERAÇÕES FINAIS}

Procurei, ao longo deste trabalho, apresentar as características que permitissem considerar os contos de Arinos e Cruls e o romance de Azevedo como obras que dialogam com a tradição da literatura sobre vampiros. Embora as narrativas analisadas não optem pela via sobrenatural - e se furtem a uma confirmação de suas personagens como vampiras -, é inegável que a arquitetura dessas obras abre essa interpretação para os seus leitores. Ademais, cabe aqui parafrasear o que David Punter (1996, p.60) afirma a respeito das obras góticas. Para o teórico, a racionalização dos elementos sobrenaturais de nenhuma forma anula o fato de que os autores góticos exploram o terror e o horror originados das fantasmagorias presentes em suas respectivas obras. Guardadas as devidas proporções, o mesmo pode ser afirmado em relação ao corpus ficcional deste artigo, que explora elementos do vampirismo e os horrores suscitados por essa monstruosidade arquetípica, mesmo que os personagens nem sempre sejam explicitamente apontados como tal.

Ademais, a escolha pelo realismo em detrimento do sobrenatural não é rara em nossa literatura. Em verdade, grande parte da ficção que investia em convenções da literatura gótica ou fantástica recebeu uma severa recepção crítica - foram qualificadas como ficções alienadas, afetadas, exageradas, e os elementos sobrenaturais foram considerados uma transgressão à verossimilhança da narrativa. Logo, esse tipo de ficção foi taxado com baixo valor literário e muitas dessas obras foram excluídas de nossa historiografia.

Suponho, pois, que tal fenômeno ajude a compreender por qual motivo a literatura do século XIX até meados do XX não investiu no 
vampiro ficcional como as literaturas de língua inglesa e a literatura francesa. Aos autores brasileiros restavam poucas opções para a inserção de um tema caracteristicamente sobrenatural como é o tema vampírico. A solução foi transformar o redivivo em metáfora - tal como em "A esteireira", A mortalha de Alzira e "Noites Brancas". Flexível como é o mito do vampiro, ele permitiu sem maiores problemas as figurações de mal e de morte, de sexo e de enfermidades, e de diversos outros aspectos negativos com que lidamos em nossa condição de seres humanos. Por fim, se o vampiro não encontrou no Brasil oitocentista uma terra tão fértil quanto a da Inglaterra, onde pudesse aportar e atacar suas vítimas - à maneira do Drácula de Bram Stoker -, essa criatura deixou certos traços significativos em nossa literatura e sem dúvida serviu como forma de representar os nossos medos mais obscuros e mais íntimos, sem perder a sua famigerada maldade.

\section{REFERÊNCIAS}

ANJOS, Augusto dos (s/d). Eu/Outra poesia. São Paulo: Círculo do Livro.

ARINOS, Afonso (2006). "A esteireira". In: Contos. São Paulo: Martins Fontes. p.51-62.

AUERBACH, Nina (2009). "Foreword". In: SKAL, David J. Romancing The Vampire: From Past To Present. Atlanta: Whitman Publishing LLC. p.4-6.

AZEVEDO, Aluísio (1894). A mortalha de Alzira. Rio de Janeiro: Fauchon \& Cia.

BíBLIA SAGRADA (1992). Centro Bíblico Católico, Frei João José Pereira de Castro (Trad.). 86.ed. São Paulo: Editora Ave Maria.

BROWN, Donald F. (1945). “Azevedo's naturalist version of Gautier's La Morte Amoureuse". Hispanic Review. (13)3, 252-257.

CABRAL, Luciano (2017). "Medo e monstruosidades". In: FRANÇA, Júlio. (Org.). Poéticas do mal: a literatura do medo no Brasil (1840 - 1920). Rio de Janeiro: Bonecker. p.201-224. 
COHEN, Jeffrey Jerome (2000). "A cultura dos monstros: sete teses". In: SILVA, Tomaz Tadeu da. (Org.). Pedagogia dos monstros: os prazeres e os perigos da confusão de fronteiras. Belo Horizonte: Autêntica. p.23-60.

COLERIDGE, Samuel Taylor (2010). "Christabel”. In: COSTA, Bruno. (Org.). Contos clássicos de vampiro, Byron, Stoker e outros. Bruno Gambarotto (Trad.). São Paulo: Hedra. p.241-263.

CRULS, Gastão (1951). "Noites Brancas". In: Contos Reunidos. Rio de Janeiro: José Olympio. p.59-71.

FRANÇA, Júlio; SANTOS, Ana Paula Araujo dos (2018). "As artes e os atributos do mal". In: As Artes do Mal: Textos seminais. 1.ed. Rio de Janeiro: Bonecker. p.13-21. GAUTIER, Théophile (2010). "A morta amorosa”. In: COSTA, Bruno. (Org.). Contos clássicos de vampiro, Byron, Stoker e outros. Marta Chiarelli (Trad.). São Paulo: Hedra. p.123-161.

GROOM, Nick (2018). The Vampire; A New History. Great Britain Yale University Press, New Haven and London.

LECOUTEUX, Claude (2005). Histórias dos Vampiros: autópsia de um mito. Álvaro Lorencini (Trad.). São Paulo: Editora UNESP.

LE FANU, Sheridan (2010). Carmilla - A vampira de Karnstein. José Roberto O’Shea (Trad.). São Paulo: Hedra.

MENDES, Leonardo (2016). "Biblioteca do Solteirão: o livro pornográfico nas conexões Brasil-Europa no final do século XIX". In: ABREU, Márcia. (ed.). Romances em movimento: A circulação transatlântica dos impressos. Campinas: Ed. Unicamp.

SENA, Marina (2017). "Sombras no romance experimental: o decadentismo de Aluísio Azevedo". In: BARROS, Fernando Monteiro de; COLUCCI, Luciana; FRANÇA, Júlio; SILVA, Alexander Meireles da. (Orgs.) Estudos do Gótico. Rio de Janeiro: Dialogarts. p.99-109.

SILVA, Alexander Meireles da (2010). "Introdução". In: COSTA, Bruno. (Org.). Contos clássicos de vampiro, Byron, Stoker e outros. São Paulo: Hedra. p.9-41. PUNTER, David (1996). The Literature of Terror. 1. 2.ed. London: Longman. STOKER, Bram (2014). Drácula. José Francisco Botelho (Trad.). São Paulo: Penguin Classics/Companhia das Letras. 